\title{
Shrinking Protection Space Through Gatekeeping and Fencing Strategies: The impact of EU's Vigration Control on the Protection of Asvlum Seekers and Forced Migrants at EU's External Borders
}

\author{
Cristina CIIURRUCA MUGURUZA
}

\begin{abstract}
1bstract: Forced migrants fleeing violent conflict, human rights abuses, persecution and other threats to life and livelihoods are entitled to the protection of their fundamental rights. Nthough in proportion there are few seeking refuge in the EU their protection space at external borders is shrinking. Starting with an explanation for the growing sophistication and inhumanity of European policies this article seeks to highlight the impact of the European migration control on the protection of forced migrants. It shows how in the complex framework of the European management and control of migration policy, border spaces of un-protection have been created through gatekeeping and fencing strategies at EU external borders.
\end{abstract}

Kevwords: Protection - forced migrants - migration management gatekeeping and fencing strategies

\section{(A) IXTRODUCCTIO)}

Protection is widely understood in terms of rights. This rights-based approach to protection is most clearly summarized in the definition provided by in 1999 by a wide group of humanitarian and human rights organizations regularly convened by the International Committee of the Red Cross in Geneva. This definition which has been adopted by the Inter Agency Standing Committee (I ASC) and the U YCIIR among other agencies affirms that protection is:

'all activities aimed at ensuring full respect for the rights of the individual in accordance with the letter and the spirit of the relevant bodies of law, i.e. human rights law, international humanitarian law and refugee law."

Protection, in these terms, has a double dimension: the recognition that people have fundamental rights to protection and the obligations of duty bearers to respect these rights, that is, to ensure protection. When states are unwilling or unable to provide this protection because of violent conflict, human rights abuses, persecution and other threats to life and livelihoods, people are often forcibly displaced and seek protection outside their countries. Under these circumstances foreed migrants and asylum seekers are entitled to the protection of their fundamental rights. ${ }^{2}$

ar Irlicle published on .31 December 2019

Professor of International Relations, University of Deusto (Spain). Mail: cristina.churruca $a$ deusto.es. This article was written within the context of the research project 'The European Union's policies on ass lum: confluences between the internal and the external dimensions' (I)ER-20r7-82/66-R), funded by the Spanish Ministry of Econom and Competitiveness and FEDER, as well as the Jean Monnet Chair EU Economic and Legal Integration for People, E AC/ Ao3 2016 (2017-2020).

S. Giossi Caverzasio, Strenglhening Prolection in II ar: a Search for Professional Slandards (ICRC, Geneva, 200I), at 19.

2 The Report of the II orld Commission on Forced Displacement argue that given the multiple factors and motives propelling forced displacement, and the complex and fluid patterns and processes of displacement (...) international intervention should be predicated on the needs and rights of the forcibly displaced, irrespective of the category or cause of 
Within the global context, the proportion of those displaced by crisis secking refuge in the $\mathbf{E U}$ is very small. ${ }^{3}$ Vigration flows are mixed, meaning that economic migrants travel the same routes as asy lumseekers and refugees. Human rights concern of these mixed flows include the need to reduce or prevent the deaths of migrants on their way to Europe, to help families to know the fate of their missing relatives and to identify and process asylum seekers in order to protect refugees and their rights. Other concerns are the ill-treatment of migrants at borders, including practices that violate their freedom and security, and detention regimes at European Union's borders that do not adequately respect minimum human rights standards. Ilowever, even the respect for human dignity and the respect for human rights is a foundational value which the EU and its Member States share and are committed to promote, the protection space for astlum seekers and foreed migrants in the Union is shrinking.'

The EU's approach to migration control forms part of a global process of containment of unwanted migrations and outlawing of the ability of the world's poor and marginalize to circulate. This process has been accompanied by a constant erosion of the rights of migrants and refugees and asy lum seekers to enter and settle in developed countries. There is also a resistance to finding the means to implement a normative doctrine of protection and a preference for managing protection through case and situation specific policies and instruments. ${ }^{5}$ From this starting premise, the aim of this article is twofold. On one hand it wants to provide an explanation for the growing sophistication and inhumanity of European polities which leads to increasingly smaller spaces where migrants can claim their rights and be treated with dignity. On the other hand, it seeks to highlight the impact of the European migration control on the protection of forced migrants and asylum seekers at EU external borders. In particular it wants to show how in the complex framework of the European policy of management and control of migration, border spaces of un-protection have been created through gatekeeping and fencing strategies. In order to do so, it will first investigate alternative conceptual diagnosis to understand European border security and migration management dynamies. Then to understand how the protection space of foreed migrants at the EU borders is shrinking, the EU legal and policy framework in the field of migration will be briefly set out.

\section{(B) INTERPRETI GEU'S BORDER PROTECTIO\ CRISIS}

Since the early rg9os, rich states and international agencies have increasingly moved towards a policy of

displacement. Rights to protection and other entitlements belong to everyone, and most certainly to forcibly displaced people. They are not contingent on a particular legal status.' Chumir Foundation for Ethies in Leadership and the I Iumanitarian Policy Group of the Overseas Development Institute (OD), Research Report II orld Commission on Forced Displacement ( Vew York, June 2019).

3 U \CIIR, Global Trends. Forced displacement in 2018 (U \CIIR, Geneva, 2019), at 18-22.

i Roger Zetter proposes the concept of protection spaces to better explain the protection needs of forced migrants. Spaces refer to the different «geographies» in which forced migrants including refugees and asy lum seekers find themselves at different temporal stages of their journeys. This concept underlines the imperative to look at «needs-based» or «rights-based» protection instead of or in addition to the conventional, «status-based protection» as the only or a sufficient response to current migration challenges. See, R. Zetler Prolecting Forced Vigrants: I Slate of the Arl Report of Concepls, Challenges and II avs Forward (Swiss Federal Commission on Migration, Bern, 201/).

Ibid. al 63 . 
containment designed to prevent unwanted migrants and asylum seekers from leaving their countries of origin. Castles gives several reasons to explain this process. First, foreed migration is growing in volume and importance as a result of endemic violence and human rights violations. Second, policymakers try to implement differential policies for different categories of migrants. Third, there is a growing understanding that migration, both economic and forced, is an integral part of global and regional economic integration processes. Fourthly, it has become clear that immigrants do not simply assimilate into host societies, but instead tend to form communities and retain their own languages, religions and cultures. Finally, migration has become highly politicized and is now a central theme of both national and international policy. ${ }^{6}$

Much of the political class and population of immigrant-receiving countries perceive immigrants from poor countries in the South as a problem for national identity and social cohesion, and even as a threat to national security. This is part of a securitization agenda in which the excluded South is perceived as a source of conflict, terrorism and instability and in which the idea of national and international security takes precedence over human security. As Iluy smans points out, the Europeanization of migration policy favours the securitization of migration, which supports a radical political strategy aimed at excluding certain categories of people by considering them as a danger (for example, to cultural values, to the provision of social assistance, to public security, to health, etc. ${ }^{7}$. Non-governmental and social organizations such as the church have criticized the demonization of migrants and the use of language that deprives them of their human condition by treating them as threats.

Along with the dynamies of securitization, it is undeniable that a strong humanitarian discourse focused on the protection of migrants has also emerged. ${ }^{9}$ Both discourses of securitization and humanitarianism have a long history of several decades in the context of the European Union but their interaction in the field of border security and migration management has intensified and gained significant momentum in recent years, especially, as it will be mentioned in the next section, since the Arab Spring and the adoption of the Global Approach to Migration and Mobility. In fact, the same border security authorities that committed themselves to saving the lives of 'irregular' migrants are also complicit in creating the conditions that make them vulnerable to various forms of violence, both directly and indirectly. The humanitarian discourse has been co-opted and used by the authorities themselves who commit human rights violations to justify the obstruction and prohibition of independent search and rescue missions of civil society in the Mediterranean or the practice of summary returns in land border control operations on the Southern Border. In recent years, EU discourse reflects a change towards an increasingly human rights friendly narrative that depicts migrants as victims and smugglers as

6. S. Castles, 'The International Polities of Forced Migration', 46-3 Development, (2003) 11-20 |doi: $10.1177 / 10116370030463003$

J. Muysmans, 'The European Union and the Securitization of Migration', $3^{8-\preceq}$.Journal of Common Markel Studies (2000) $75^{1}-77$ |doi: $\left.10.1111 / 1 / 68-5965.00263\right)$.

8 M. White and R.Sval, 'Archbishop of Canterburv: 'don't demonise immigrants', The Cuardian, 27 Octubre 201/4."

9 P. Pallister- W ilkins, "The Ilumanitarian Polities of European Border Policing: Frontex and Border Police in Evro", 9I Inlernational Political Sociologr (2015), ,3369 
perpetrators" of migrants death and abuse at sea' ." In general there is a growing criminalization of hospilality practices and solidarity with irregular migrants which has been described by Carrera as "policing humanitarianism'."

The growing sophistication and inhumanity of European migration control policy cannot be explained only appealing to the contradictions between discourse and practice in migration management policy. The process of (in) securitization of border control entails practices whereby the deaths turned into public spectacle of some people while attempting to enter the EU justify discussing the legitimacy of these border control policies, while masking the situation of the tens of thousands of people detained and returned, as well as the number of people prevented from entering the EU. As Vaughan-Williams highlights it is not only that the EU's borders are in crisis, but also that the basis on which border security authorities could be challenged and held accountable is also in crisis ${ }^{12}$

The biopolitical perspective offers interesting analy tical possibilities to explain this process and the persistently violent nature of EU border control. Foucault's conception of a biopolitical regulation of life, a technology of capitalism's own government and at the same time a condition for its development, provides a conceptual framework to interpret the current management of migration. ${ }^{33}$ With these lenses the global prohibition of undocumented and spontaneous migration is understood as a new manifestation of the security-development nexus and the intereonnection between racism, migration and development become a fundamental element of biopolitical governance't.

Different authors have used Giorgio Agamben's work to better understand the 'negative' dimensions of these biopolitical border practices: the so-called Thanatopolitical' dynamic that often exposes 'irregular' migrants to dehumanising and lethal conditions ${ }^{15}$. Agamben reintroduces the role of sovereign power to recover the violent potential of the tanatopolitical drift within biopolitical forms of governance $^{16}$. Other scholars of critical studies on borders and migration largely reject Agamben's theses

1) V. Moreno Lax, 'The EU Mumanitarian Border and the Securitization of Iluman Rights: The 'Rescue-ThroughInterdiction Rescue-W ithout-Protection' Paradigm', 56- .JCWS (2018), 119 1/40 at 11977 |doi: 10.11n1 jems.12651|.

"The notion of "policing humanitarianism' has emerged to describe not only cases of formal prosecution and sentencing in criminal justice procedures, but also wider dynamics of suspicion, intimidation, harassment and disciplining. See, S. CARRER \, Fil for purpose.' The Facilitalion Directive and the criminalisalion of humanilarian assistance to irregular migrants: 2018 I pdate, Policy Department for Citizens' Rights and Constitutional Affairs Directorate General for Internal Policies of the Union PE 6o8.838 - December 2018.

12 I. Vaughan-W Williams, Europe’s Border Crisis. Biopolitical Security and Beyond (O\ford University Press: London, $2015), 121-151$

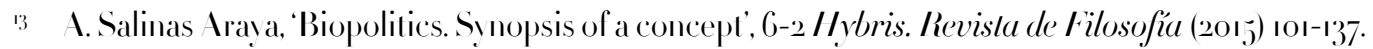

'1 M. Duffield, 'Racism, migration and development: the foundations of planetary order', 6-ı Progress in Development Studies (2006) 68-79.

I.5 Cfr. Bigo, D., 'Detention of Foreigners, States of Exception, and the Social Practices of Control of the Banopticon' in Rajaram, P.K., and Grundy - Warr, C., Borderscapes: IIidden Geographies and Politics al Terrilory's Edge (Universily of Minnesola Press: Minneapolis, M \, 2007) 57 I0I.; De Genova, \. and Peulz, \., (Eds.), The Deporlalion Regime: Sovereignly, Space, and the Freedom of Iovement (Duke University Press, Durham, VC and London, 2010); Kinnvall, C. and VesbiltLarking, P., 'Securitising Citizenship: (B)ordering Practices and Strategies of Resistance’. 23-3 Global Sociely (2013) 337 .59 |doi: 13600826.2013 .790786 .

16. Agamben, G., Ilomo sacer. Sovereign power and bare life, Stanford University Press, Stanford, C. I, 1998; Agamben, G., Veans Wilhoul Ends, University of Minnesola Press, Minneapolis, M \, 2000. 
warning that an exclusive focus on thanatopolitics, which privileges sovereign power and control over political struggle and dispute, does not take into account the role of the migrant's agency in the configuration and resistance of contemporary border regimes ${ }^{17}$. They claim a different view that, as Sandro Medrazza points out, prioritizes the subjective practices, desires, expectations and behaviours of the migrants themselves". Based on Esposito's work and resorting to Derrida's concept of 'hostipitality', the work of Vick Vaughan-W illians is of special interest. He calls for a reconceptualization of the border as a place of encounter with the Other"ts.

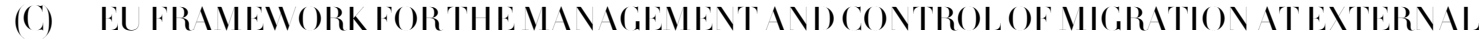
BORDERS

The EU migration policy constitutes a complex patchwork collection of both political and legal instruments, cooperation arrangements, as well as a wide range of operational and capacity-building programmes involving many different actors. This management system has three main components: action inside the Union, action with partners outside the Union and action at EU external borders. This section only briefly outlines the competence and the existing EU policies that manage and control migration claiming to protect the human rights of migrants at the EU borders. ${ }^{20}$

The Amsterdam Treaty of 1999 made the EU (then European Community) competent for migration and asylum policies. Since the entry into force of the Lisbon Treaty in December 2oog, the EU and its Member States share competence in the Area of Freedom, Security and Justice (AFSJ) (Article 4(2)(j) Treaty on the Functioning of the European Union (TFEU). Article 67(1) TFEU provides that the EU 'shall constitute an | XFS.J with respect for fundamental rights' (emphasis added). The Court of Justice of the European Union (C.JEU) has now jurisdiction to review legislation that would not meet human rights standards. In addition, Article 3.2 TEU calls for 'appropriate measures with respect to external border controls'. The EU therefore sets out to establish common standards about controls at its external borders. Articles 78 and 79 TFEU lay down the legal basis for EU action to prevent irregular immigration and protect the rights of migrants at EU external borders. Article $78(\mathrm{I})$ provides that $\mid$ th he Union shall

${ }_{7}$ Contributions from the autonomy of migration approach conceive migration as a creative force within the social, cultural and economic structures. See, Garelli, G.y Tazzioli, M., 'Counter-mapping, Refugees and Asylum Borders' en Mitchell, K., Jones, R.y Fluri, J.L, IIandbook on Crilical Geographies of Migration (Edward Elgar Publishers:Cheltenham, Jorthamton, M I, 2019) 307-109; Garelli, G. and Tazzioli, M., 'Containment beyond detention: The hotspot system and disrupted migration movements across Europe', Environment and Planning D): Sociely and Space (2018) |doi: 10.1177/0263775818759335); R. Esposito, "Biopolítica y filosofía de lo impersona" in R. Esposito, El disposilivo de la persona (Amorrortu: Buenos Aires, 20u); A. Mcnevin, 'Ambivalence and Citizenship: Theorising the Political Claims of Irregular Migrants', 1-2 Villennium: Journal of Inlernational Studies ( 2013) 182 200 |doi: 10.1177 0305829812/63373).

18 S. Medrazza, The gaze of autonomy: capitalism, migration and social struggle' in V. Squire (Ed.), The Conlesled Polilics of Mobility Borderzones and Irregularily (Roulledge, London, 20I0) I2I-I/22.

19 Vaughan- IV illiams, supra n.13, at 123.

${ }^{20}$ F. Altina, Tackling the migrant wave: EU as a source and a manager of crisis', 7o-2 Revisla española de derecho inlernacional (2018) 49-70, |doi: 10.17103 redi.70.2.2018.ı.02| and J.M. Goig Marlínez, 'La política común de inmigración en la Unión Europea en el sesenta aniversario de los Tratados de Roma (o la historia de un fracaso), $3^{2}$ Revisla de Derecho de la Unión Europea. Madrid ( 2017) 71-111. 
develop a common policy on asylum, subsidiary protection and temporary protection with a view to offering appropriate status to any third-country national requiring international protection and ensuring compliance with the principle of non-refoulement' and that 'Ithis policy must be in accordance with the Geneva Convention of 28 .July 19.5I and the Prolocol of.3I January s.g67 relating to the status of refugees, and other relevant treaties' (emphasis added). ${ }^{21}$ Article $79^{(\mathrm{I})}$ states that 'Ithe Union shall develop a common immigration policy aimed at ensuring, at all stages, the efficient management of migration flows, fair treatment of third-country nationals residing legally in Member States, and the prevention of, and enhanced measures to combat, illegal immigration and trafficking in human beings'. This requires a common policy on external border management. Article 3.2 TEU calls for 'appropriate measures with respect to external border controls'. The EU therefore sets out to establish common standards with regard to controls at its external borders and to gradually put in place an integrated system for the management of those borders. In addition migration has also become a specific component of the EU's Common Security and Defence Policy (CSDP). CSDP missions and operations have been adopted with the aim of tackling migrant smuggling, such as Operation Sophia (EU N I F OR Med) ${ }^{22}$ and the EU integrated border management assistance mission in Libya (EU B A M Libya). ${ }^{23}$

The Global Approach to Migration (G. M M) was first defined by the European Council in December $2005^{2}{ }^{2}$ It was the first attempt to address the whole range of migration related issues with third countries in the area of migration and asy lum. The approach comprises the whole migration agenda, including legal and irregular migration, combating trafficking in human beings and smuggling of migrants, strengthening protection for refugees, enhancing migrant rights and harnessing the positive links that exist between migration and development. The Stockholm Programme adopted in 2009 also acknowledged the importance of consolidating, strengthening and implementing the global approach to migration. ${ }^{25}$

In 201, coinciding with the increment on the irregular arrivals by sea and land caused by the "Arab)

${ }^{21}$ The current legal standards of the EU setting out the fundamental right to asvlum are the Asvlum Procedures Directive $20133^{2}$ EU, the Reception Conditions Directive 201333 EU, the Qualification Directive 2011/95 EU (which are currently in the process of being revised), as well as the EU Charter on Fundamental Rights. The application of those instruments should in any case be compliant with the European Convention on I luman Rights and the Geneva Convention. For a critical commentary on the European Commission's proposal for the reform of the Common European Asylum System presented in 2016 and how it erodes migrants human rights see Joana Abrisketa article "The reform of the Dublin III Regulation: how to build or not to build further enforeing mechanisms" in this volume.

${ }_{22}$ F.V acas Fernández, The European operations in the Mediterranean Sea to deal with migration as a symptomFrom the Italian operation Mare Nostrum to Frontex operations Triton and Posseidon, EU X I V FOR-MEI) and X ATO's assistance in the Aegean Sea', 20 Spanish yearbook of inlernational law, (2016) |doi: 93-117 10.1177 00113921166-8089).

${ }_{23} \mathrm{O}_{\mathrm{n}} \mathrm{z}_{7}$ December 2018, the European Council amended and extended the mandate of the European Union Integrated Border Management Assistance Mission in Libya (EU B A V Libya) from a January 2019 until 3o June 2020 to actively support the Libvan authorities in contributing to efforts to disrupt organised criminal networks in olved notably in smuggling migrants, human trafficking and terrorism. Council Decision (CFSP) $2018 / 2009$ of 17 December 2018, OJ 2018 L $32222_{2}$.

2 At the Justice and I Iome Affairs Council meeting on I December 2005 , the Commission presented its Communication: 'Priority actions for responding to the challenges of migration: First follow-up to Hampton Court' (doc. 1520/4 o-g). The matter was considered by the General Affairs and External Relations Council on r2 December 2005 and adopted by the European Council on 13 December (ST 1574 2005 INIT EX, 13.12.200 ).

${ }_{25}$ European Commission, 'Delivering an area of freedom, security and justice for Europe's cilizens Action Plan Implementing the Stockholm Programme', COM (2010) Iz Iinal, Brussels, 20.4.2010, al 8. 
spring, the global approach was evaluated. As a result the Commission adopted a renewed Global Approach to Migration and Mobility (G IMM) to build up a coherent and comprehensive approach to collect the benefits and address the challenges deriving from migration ${ }^{26}$. The G AMM focuses on four main priorities: improving the organisation of legal migration and facilitated mobility, preventing and reducing irregular migration in an efficient, yet humane way, strengthening the synergies between migration and development, and strengthening international protection systems and the external dimension of asylum. G I M M claims to take into account the human rights at stake in movements across borders, by placing emphasis on establishing legal channels of migration and protecting human rights, including international protection. It expressly purports to be 'migrant-centred', mentioning the human rights of migrants as a cross-culling issue. ${ }^{27}$

Protection of forced migrants is also an explicit concern of the June 201/4 European Council strategie guidelines for legislative and operational planning within the AFS.J for the 2015 -2020 period. The guidelines stress the need to adopt a holistic approach to migration, making the best possible use of regular migration, affording protection to those who need it. ${ }^{28}$ Yet combating irregular migration and managing borders effectively is the main concern. ${ }^{29}$ The Guidelines raise questions about the role of the EU Charter of Fundamental Rights and rule of law in the AFSJ and how access to international protection of asylum seekers and refugees will be guaranteed. $3^{\circ}$

The unprecedented migration and so-called refugee crisis in the Mediterranean triggered the adoption of the European Commission European Agenda on Migration on 13 May 2orj. The Agenda purpose is to set up a comprehensive framework a to address immediate challenges and equip the EU with the tools to better manage migration in the medium and long term in the areas of irregular migration, borders, asylum and legal migration' ${ }^{31}$ The Agenda proposes immediate measures to cope with the crisis in the Mediterranean and measures to be taken over the next few years to manage all aspects of immigration more effectively. In the longer term it proposes three areas of action: the completion of the Common European Asylum System, a shared management of the European border and a new model for legal migration. ${ }^{32}$ To implement the Agenda, the Commission identified priority actions that has led to the development of 'a new EU migration infrastructure, with new laws, new systems for coordination and cooperation, and direct operational and financial support from the EU' to ensure a more humane and efficient migration management. ${ }^{33}$ The question is, does this system ensure a human rights based

26. European Commission, 'The Global Approach to Migration and Mobility', COM (2011) 7亿3 final, Brussels, 18.11 .2011 at 2.

${ }^{27}$ Ibid. $j^{-6 .}$

${ }_{28}$ European Council, Conclusions, 26 27 June 201/, EU CO 79 1/, Brussels, 27 .o6. 201/, paras. 7-8.

29 Ibid. Para 9

$3^{\circ}$ S.Carrera and E.Guild, The European Council's Guidelines for the Area of Freedom, Security and Justice 2020 Subverting the 'Lisbonisation' of Justice and IIome Affairs?' "CEPS Essay Vo. 13/1/4 (201/) at ro.

${ }^{31}$ European Commission, 'A European Agenda on Migration’, COM (2015) 240 final, 13.5.2015 al 2.

$3^{2} \quad$ Ibid. 17-18.

33 For a detailed report on the implementation of the Agenda see: European Commission, Communication from the Commission to the European Parliament, the European Council and the Council, Progress report on the Implementation of the European Igenda on Migration, Brussels, COM (2019) 48 final, I6.10.2019. 
migration management in particular in the EU external borders?

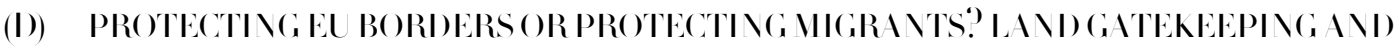
FE\CINGSTR ITEGIES

The so-called EU's migration comprehensive policy framework has been described as a comprehensive and robust non-entrée regime. ${ }^{31}$ 'Fortress Europe' has been built to protect European borders and to address the so-called mobility-migration-citizenship nexus. ${ }^{35}$ This non-entrée regime has persistently reduced the protection space for refugees, asylum seekers, forced migrants and in general people in mixed migration flows within the EU. ${ }^{6}$ The increase in mixed migration flows into the EU and heightened security concerns have strengthen the focus on protecting the EU's external borders. The prevention of and combat against irregular migration to the EU is one of the few areas where member States have been able to find common ground. With this aim there has been an increasing interest on developing ways of controlling the access and stopping refugees and irregular migrants crossing the EU's external borders. ${ }^{37}$ Border migration control policies can be distinguished on the basis of whether they follow a "gatekeeping' or a 'fencing' strategv. Gatekeeping strategies aim at controlling and restricting migrants' access to protection from European Union and Member States institutions on land or at sea. ${ }^{8}$ Fencing measures actively target illegal migrants to stop them from entering to the EU territory and expel them in case they enter.

A gatekeeping strategy on land is the European Commission idea of selling up 'Itotspots' to assist

34 See, Orchard, P. The non-entrée regime. In A Right to Flee: Refugees, Stales, and the Construction of Inlernalional Cooperalion (Cambridge: Cambridge University Press, 201/), at 203-237 |doi:10.1017 CBO9781139923293.0o8|; R. Zelter, R., "Creating Identities - diminishing protection: securitising asylum seeking in the EU MS", in Kneebone, S., Stevens D., and Baldassar., L. (eds), Refugee Prolection and the Role of Law: Conflicting Identities (Abingdon: Routledge, 2014), at 22 35.

35 S. Carrera (Ed). The Vexus belween Immigration, Inlegration and Cilizenship in the EU. Collective Conference Volume/April 2006, 2 CEPS Challenge Papers (2006).

$3^{6}$ In parallel it has minimized the possibility of legal routes to access asvlum while it has progressively externalized migration control outside European borders. To put it bluntly, the denounce made by the Special Rapporteur on the human rights of migrants, Francois Crépeau in 2013 that the European Union washes its hands of its responsibility of guaranteeing the human rights of those persons attempting to reach its territory' still applies today. Ituman Rights Council, Report of the Special Rapporteur on the human rights of migrants, François Crépeau, 'Regional Studs: management of the external borders of the

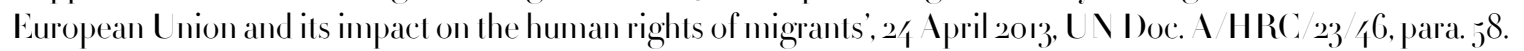

37 The EU-Turkes Statement from March 2016, which is closelv linked with the implementation of the hotspot approach in Greece, aims to reduce the irregular migration flows from Turkev to the EU. Other measures for protecting the EU's external borders have focused on reinforcing EU border management rules, such as the Schengen Borders Code, and strengthening and upgrading the mandates of relevant EU agencies, such as Frontex, EU-LIS I, Europol and E ASO. On the other hand, in connection with a number of kev shortcomings in the EU's information ssstems, efforts were made to improve use of the opportunities offered by information svstems and technologies for security, criminal records, and border and migration management. This included strengthening existing IT sustems (SIS II, I IS, Eurodac, ECRIS-TCX), establishing new ones (ETI AS, Entry Exit Sustem) and improving their interoperabilits. For an overview of EU policies and actions that focus on the protection of the external borders against so-called 'illegal' immigration and the return of illegally staving migrants before entering the EU by sea, see: S. Cogolato et al, Migrants in the Mediterranean: Protecting human rights, (European Parliament,

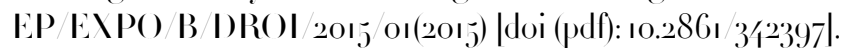

$3^{8} \quad$ A. Triandafillidou, 'Controlling Migration in southern Europe (Parl ı): Fencing Strategies', 7 AR/ (2010) at I. 
frontline Member States, namely Italy and Greece, confronted with disproportionate numbers of arrivals in registering those who come; addressing initial reception needs; identifying vulnerabilities and undertaking security checks. ${ }^{39}$ Asylum and return procedures may also take place in the hotspots. The hotspot approach introduced by the Commission in the European Agenda on Migration in 2015 was formally endorsed by the Justice and Home Affairs Council meetings of $25^{-26}$ June $2015^{-1^{\circ}}$ It has since 2015 applied to all disembarkations of migrants reseued at sea as well as to unauthorised landings in the Eastern Aegean islands and in the most affected areas of Southern Italy. With a capacity of over, $55^{\text {Oo }}$ places per hotspot they host only in the five ones in Greece over 3 o,ooo. 'i' The European Asylum Support Office (EASO), the EU's law enforeement Agency (Europol) and the European Border and Coast Guard Agency (Frontex) have deployed experts directly in the hotspots to support national authorities in registering and screening new arrivals, investigating smuggling and other criminal activities, and registering and interviewing applicants for international protection. ${ }^{2}$ If officially, the hotspot approach aims at helping immigrants and States at the borders, unofficially it is a measure to deter potential immigrants from leaving and arriving at the EU.

Given the fundamental rights challenges arising FR I has been providing fundamental rights expertise to the European Commission, EASO and Frontex on diverse aspects of their operations in Greece and Italy, since the hotspot approach began mid-2org. In Vovember 20r6, FR I formulated 2 I individual opinions to address the fundamental rights shorteomings identified in the implementation of the hotspot. Despite efforts to improve the situation, many of the suggestions contained in the 2r opinions FR I formulated at the time remain valid in 2019. Taking the situation in both EU Member States logether, FRI finds that only three issues were properly addressed. On eight opinions, there have been developments without resulting in significant improvements on the ground. In to out of 2 opinions, there was no significant progress. The persisting challenges in the five areas FRA highlighted in 2016 are: international protection; child protection; identification of vulnerable people; security; return and readmissions.3 The human rights situation in the Greece hotspots has become such egregious that the head of FRA, Michael O'Flaherty, consider's the plight of trapped migrants on the islands 'the single most worrying fundamental rights issue that we are confronting anywhere in the European Union.’’x

39 European Commission, The I/olspol approach to managing exceplional migralory flows, 2015. Other EU gatekeeping strategies are the operations for sea border surveillance like Frontex, the Schengen Border Code, the Internal Security Fund and the CSIOP operations against human smuggling and trafficking networks.

to M.M. Mentzelopoulou and K. Luylen, 'Motspots at EU external borders State of play', European Parliamentary Research Service, PE 623:563 (2018) al 2.

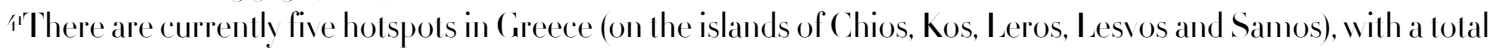
capacity of $633^{8}$ places. Another five hotspots were established in Italy (in Lampedusa, Messina, Pozzallo, Taranto and Trapani), with a tolal capacity of $185^{\circ}$ places. According to U VCIIR data there are 30,700 people, mostly women and children in Greece slaving under precarious conditions pulling at risk their well-being. U VCIIR, F ICT SIIEET Greece, October 2019 .

仿 Supra n. 行, 2-1.

1.3 FR I, U pdate of the 2016 Opinion of the European I nion Agency for Fundamenlal Righls on fundamenlal righls in the holspols' sel up in Creece and Ilaly, FR 1 Opinion - 32019 lHotspols U pdatel V ienna, 4 March 2019 at 6.

任 I. Nielsen, 'Greek migrant hotspot now EU’s worst rights issue, Eurobserver, Brussels, 7 November 2019. 
Other voices have joined the agency's complaint to raise concerns about the prolonged detention of refugees and migrants in the hotspots, their deplorable conditions and the need to improve and expand reception capacity among others the U Y Iluman Rights Commiltee, U NIICR, the Council of Europe's Committee for Prevention of Torture and Inhuman or Degrading Treatment or Punishment (CPT). ha The delays in registering asy lum applications and lack of support or basic reception conditions have also been denounced by several XGOs. ${ }^{6}{ }^{6}$ The Parliamentary Assembly of the Council of Europe has expressed that 'detention of asylum seekers in the 'hotspots' on the Aegean islands may be incompatible with the requirements of the European Convention on Ituman Rights (ETS Vo. j), due notably to procedural failures undermining the legal grounds for detention and inadequate detention conditions. 'T Finally, the international president of MSF Christos Christou has called for the urgent evacuation of children and the most vulnerable from the camps. He accused European leaders of keeping some 38 ,ooo refugees and migrants trapped on Greek islands in unsafe and shocking conditions comparing the situation in camps in Greece 'to war zones and that it was outrageous to witness such conditions in Europe?. ? $^{8}$

As oppose to gatekeepingwhich is a common policy, fencing has emerged as part of individual states response to migration pressure. Before 2015, only three countries had resorted to erecting fences at external borders to prevent migrants and refugees from reaching their territories: Spain (where building work was completed in 2005 and extended in 2009), Greece (completed in 2012) and Bulgaria (in response to Greece, completed in 201/4). Contrary to Article 1/12) of the Schengen Borders Code, which stipulates that 'entry may only be refused by a substantiated decision stating the precise reasons for the refusal', an increasing number of Member States have gradually embarked on the construction of border walls or fences with the aim of indiscriminately preventing migrants and asylum seekers from accessing their national territories.99 W ithout explicit EU rules on the erection of fences at external Schengen borders, Member States have built barriers and fences with third countries (notably Morocco and Russia), including pre-accession candidates (the Republic of North Macedonia, Serbia and Turkey) and one EU Schengen candidate country, Croatia. Fences have also been constructed within the Schengen area, such as the fence between Austria and Slovenia. ${ }^{50}$

These fences are a cause for concern because of the human rights' violations committed against migrants who get extremely limited access to territory and to the asylum procedure. Although arrivals have been reduced after $20 y_{5}$, push-backs and expulsions at the border, exerted with some violence by the forces of law and order, continue to happen constantly (both in Croatia and Serbia and in Melilla). ${ }^{51}$ Persons

\footnotetext{
1.5 Supra $12,5^{-6 .}$

46. Ph. Amaral, Forgollen al the gales of Europe: Ongoing prolection concerns al the EU's exlernal border (Jesuit Refugee Service, Brussels, 2018) i6-17.

17 Parliamentary Assembly- Council of Europe, 'Ituman rights impact of the 'external dimension' of European Union asylum and migration policy: out of sight, out of rights?', Ioc. 1/307, Reference 1298 (2017), para j.

is Ch. Christou, European Leaders: Stop Punishing Asvlum Seekers on the Greek Islands, Open Letter, 27 Jovember 2019 .

19 European Parliament, 'Management of the Evternal Borders', Facl Sheels on the European I nion (20rg) at /.

Ibid.

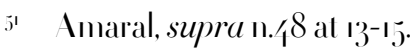


wishing to apply for asylum still do not have guaranteed access to the asylum application due to a great lack of information or ill-treatment by the authorities of the Member States. These difficulties are compounded by severe shortcomings in the translation and interpretation of languages, lack of complete information on the rights of persons arriving at borders and the obstacles posed by the Dublin Regulation in the Common European Asylum System ${ }^{j^{2}}$.

Although extrajudicial push-backs happen in almost complete impunity, there are some positive developments. Several allegations of violation of the principle of non-refoulment by member States under Article 4 of Protocol Vo. 4 to the European Convention on Ituman Rights (ETS No. 46) have been processed by the European Court of Ituman Rights. The European Court of Human Rights convicted Spain in 2017 of breaching the prohibition of collective expulsion under Article 4 of Protocol No. 4 and Article 13 of the Convention by its border control at the fences of Melilla. ${ }^{33}$ A group of Sub-Saharan migrants managed to climb the three fences, but were immediately apprehended by the Spanish civil guard and handed over to the Moroccan authorities. They were not subjected to any identification procedure nor had the chance to express their wish to apply for asy lum, let alone to receive assistance from lawyers, interpreters or medical personnel. The Spanish authorities argued that the events occurred outside their jurisdiction: as the migrants had not passed the border crossing point in Melilla, they had not entered Spanish territory. The European Court of Ituman Rights, however, made it clear that member States cannot escape their responsibility and prevent asylum seekers from making an asylum claim.

\section{(E) COXCLUSIO)}

The respect for human dignity and the respect for human rights is a foundational value which the EU and its Member States share and are committed to promote. Yet as this article has evidenced the protection space for asy lum seekers and forced migrants at the European Union external borders is shrinking. EU's non-entrée regime has persistently reduced the protection space for refugees, asylum seekers, forced migrants and in general people in mixed migration flows coming to the EU.

The EU's approach to migration control forms part of a global process of containment and oullawing unwanted migrations. The growing sophistication and inhumanity of European migration control policy cannot be explained only appealing to the contradictions between discourse and practice in migration management policy. This process should be understood as a fundamental element of biopolitical governance which exposes forced migrants to dehumanizing conditions. Despite a human rights friendly narrative there is a growing criminalization of hospitality practices and solidarity. In this context instead of choosing to protect migrants the EU has opted for a management approach to the control of migration that is gradually undermining the normative foundations of protection. Despite the official discourse there is a lack of a coherent, human rights-based approach to migration. In particular,

$5^{2} \quad$ Ibid. at 3. CE MR, Informe 2019 de la Comisión Española de Avuda al Refugiado (CE AR) Las personas refugiadas en España y Europa (CE IR, Madrid, 2019) at 6o, 74, 18.

53 X.I. and X.T. v. Spain ( 
gatekeeping and fencing strategies controlling and restricting migrant's access to protection and stopping refugees and irregular migrants crossing the EU external borders raise particular scandalous human rights concerns. Gatekeping strategies aim at controlling and restricting migrants' access to protection from European Union and Member States institutions on land or at sea. Fencing measures actively target illegal migrants to stop them from entering to the EU territory and expel them in case they enter. This practice calls into question the values of respect for human dignity and human rights on which the EU is founded. 